\title{
Cretaceous Biostratigraphy of the Grand Banks of Newfoundland\%
}

GRANT A. BARTLETT

Atlantic Oceanographic Laboratory, Bedford Institute, Dartmouth, N.S.

Introduction

This is a preliminary report on the Cretaceous biostratigraphy of the Grand Banks of Newfoundland (Fig. 1). The Cretaceous sequence of strata is several hundred feet thick and contains a diverse microfauna consisting of foraminifera, ostracods, radiolaria, diatoms and coccoliths. The macrofauna is characterized by corals, echinoids, crinoids, bryozoans, brachiopods and pelecypods. Baculites and Inoceramus are common in various sections. Algal balls are also common in certain limestones.

A detailed investigation of the Mesozoic-Cenozoic biostratigraphy, paleoecology, and paleogeography of the Canadian Atlantic Continental Margin is in progress. The study is based on samples obtained from two wells drilled by Pan American Oil Company; Grand Falls, Lat. $45^{\circ} 28,19^{\prime \prime} \mathrm{N}$, Long. $52^{\circ} 00^{\prime} 03^{\prime \prime} \mathrm{W}$, and Tors Cove, Lat. $44^{\circ} 11^{\prime} 14^{\prime} ' \mathrm{~N}$, Long. $52^{\circ} 23^{\prime} 42^{\prime \prime} \mathrm{W}$. The general stratigraphy, paleoecology and intercontinental correlation of the Grand Banks section was described by the writer at the Atlantic Continental Margin Symposium, Dartmouth, Nova Scotia.

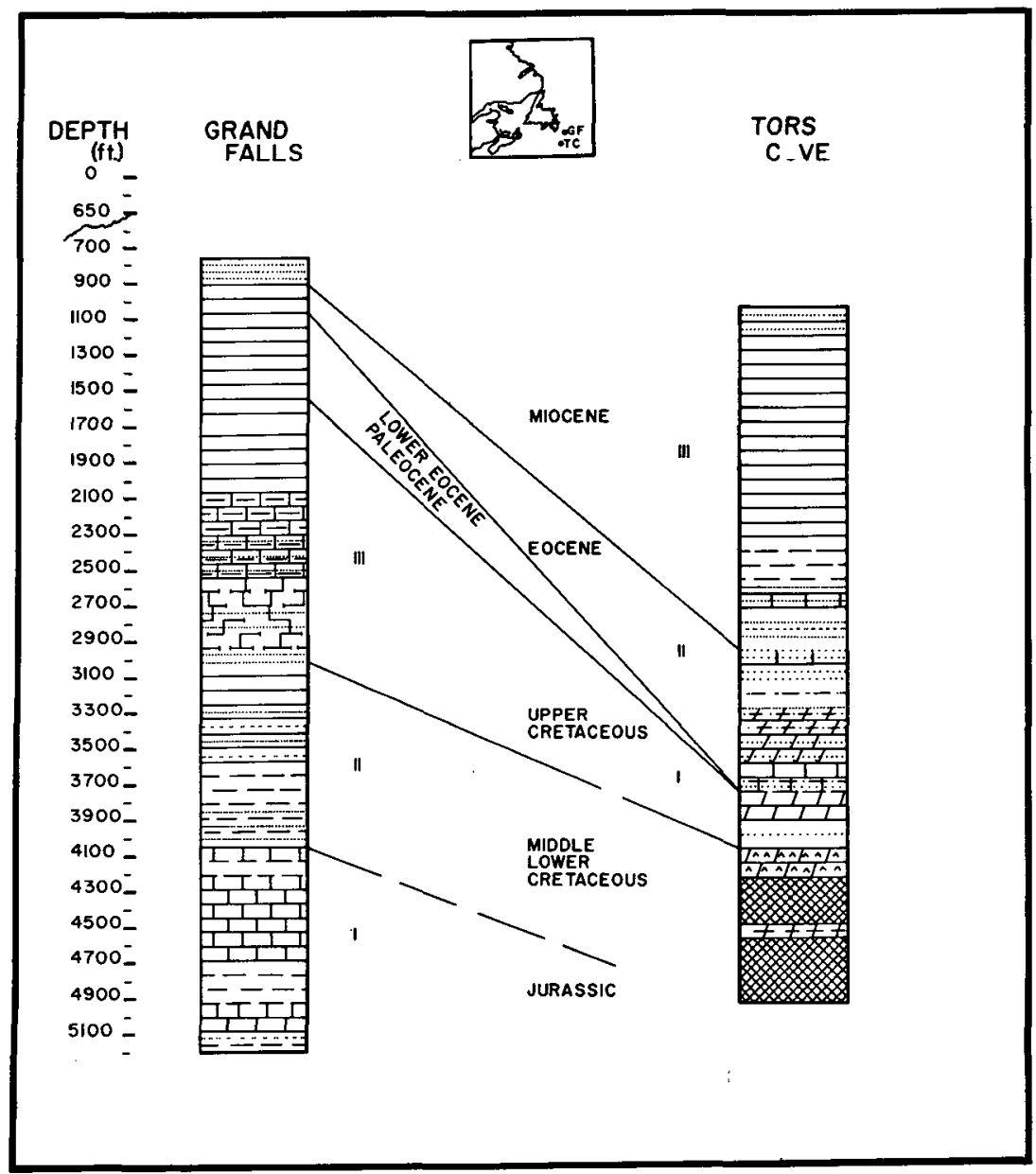

Fig. 1 Age and correlation of the Grand Falls and Tors Cove stratigraphic sections based on planktonic foraminifera. 
The Cretaceous planktonic foraminifera are dominantly Tethyan forms, and range from Neocomian (Globigerina helveto jurassic - Globigerina graysonensis zone) to the Maestrichtian (Hedbergella monmouthensis - Globotruncana fornicata zone) Figs. (2, 3). The Danian Globigerinoides daubjergensis - Globigerina triloculinoides faunas overlie the Maestrichtian in the Grand Falls section. However, the Maestrichtian in the Tors Cove section is overlain by the Lower Eocene Globorotalia rex - Globoratalia aragonensis faunas. Movement in Eocene time of a presumed underlying salt dome is suggested as a means of uplift and erosion of Paleocene strata at Tors Cove. However, the structural features of the area also suggest fluctuating tectonic activity.

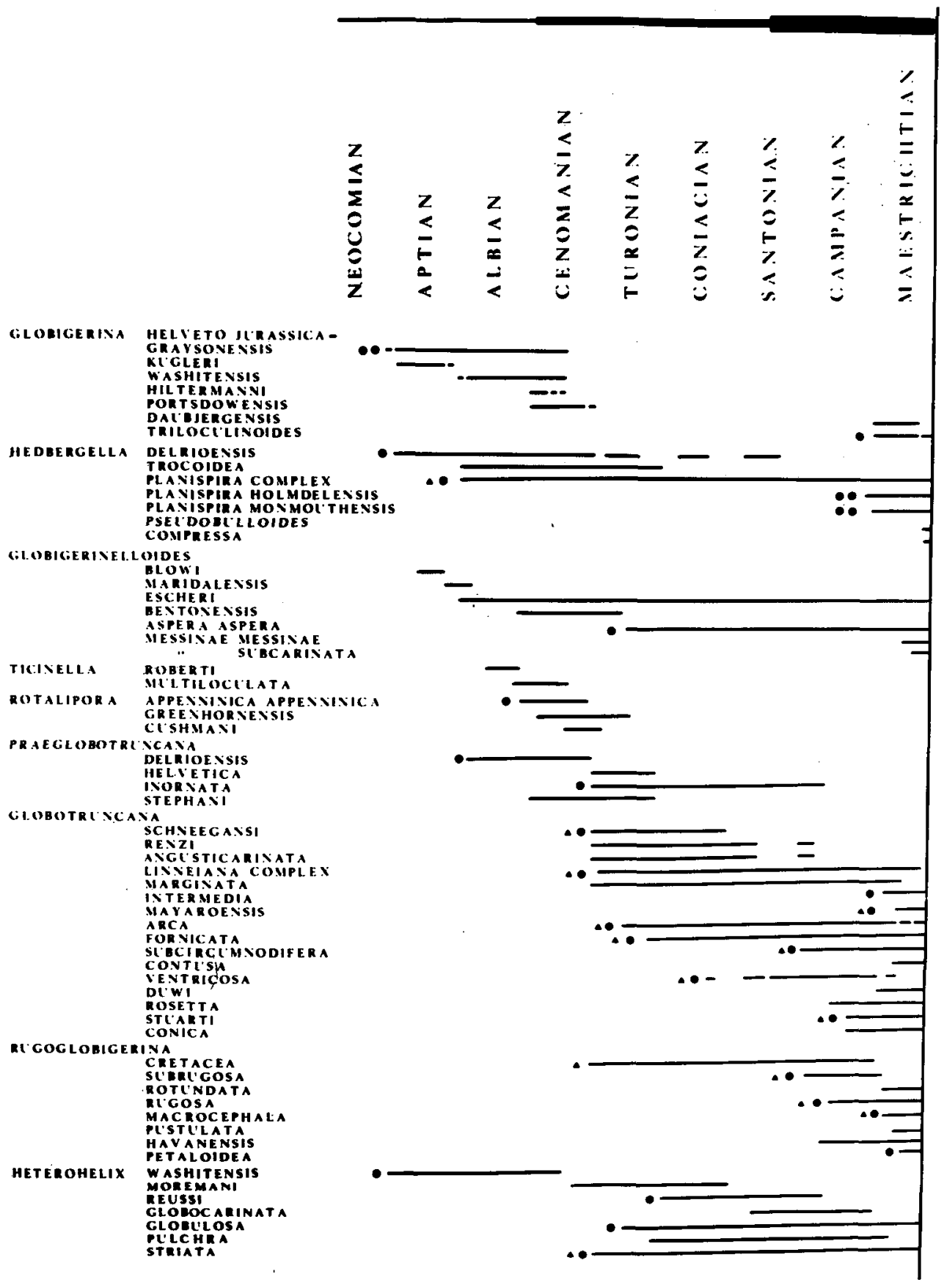

Fig. 2 Range of common planktonic foraminifera in Cretaceous sediments from the Grand Banks. Single dots indicate most common species, double dots indicate boreal species and triangles indicate tethyan. species. 
Maestrichtian

LATE

CRET ACEOUS
Navarro

Campanian

Campanian

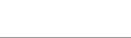

Taylor
Abathomphalus mayaroensis Globotruncana gansseri (?)

Hedbergella monmouthensis Globotruncana fornicata Rugoglobigerina rugosaGlobotruncana rosetta

\begin{tabular}{|c|c|c|c|}
\hline & & Taylor & \\
\hline & Santonian & & $\frac{\text { Globotruncana renzi-Globiger - }}{\text { inelloides subcarinatus }}$ \\
\hline & Coniacian & Austin & $\begin{array}{l}\text { Globotruncana } \\
\text { Globotruncana } \\
\text { schneeganzi }\end{array}$ \\
\hline & Turonian & Eagle Ford & Praeglobotruncana helvetica \\
\hline $\begin{array}{l}\text { MIDDLE } \\
\text { CRETACEOUS }\end{array}$ & Cenomanian & Washita & $\frac{\text { Rotalipora appenninica appenninica, }}{\text { Globigerina washitensis- }}$ \\
\hline \multirow{4}{*}{$\begin{array}{l}\text { LOWER } \\
\text { CRETACEOUS }\end{array}$} & Albian (?) & & $\begin{array}{l}\text { Globigerina washitensis - } \\
\text { Ticinella roberti (?) }\end{array}$ \\
\hline & Aptian & & $\begin{array}{l}\text { Globigerina kulgieri- } \\
\text { Globigerinelloides algeriana }\end{array}$ \\
\hline & & Comanche & \\
\hline & Neocomian & & $\frac{\text { Globigerina helveto-jurassica- }}{\text { Globigerina }}$ \\
\hline
\end{tabular}

Fig. 3 Faunal zones utilized for intercontinental correlation that may be tentatively applied to the Cretaceous sediments of the Grand Banks.

The benthonic microfauna is composed of less than twenty species of foraminifera and ten species of ostracods. The foraminifera are dominated by shelf forms such as Gaudryina bulloides, Robulus munsterii, R. navarroensis, Citharina multicostata, C. wadei, Globulina gibba, Bulimina exilis, B. reussi, Hoeglundina elegans, H. supracretaceă, Gyroidina depressa and Eponides plummerae. Characteristic ostracods are Haplocytheridea plummeri, Brachycythere crenulata, Veenia papatriplicata, Veenia ozanana, Brachycythere aff. acuminata and Bairdoppilata sp. Horizons lacking benthonic foraminifera commonly contain broken molluscs, coal fragments and vegetal matter.

\section{Previous Work}

Sediments of Tertiary age from a submarine canyon off Nova Scotia were reported by Marlowe (1965). The Oligocene-Miocene age and faunal content of this strata was reported by Marlowe and Bartlett (1967). The mid-Tertiary biostratigraphy of the Scotian Shelf was described by Bartlett (1968). Middle Cretaceous strata obtained in dredge hauls on the Scotian Shelf were reported by King et al. (1969). Cushman (1936) recorded Cretaceous for aminifera in greensands from Georges Bank. Dalby (1925) noted the presence of Cretaceous material in fish trawls from Banquereau Bank. Cretaceous faunas from the Atlantic Coastal Plain were described by Olsson (1960, 1964) and Stephenson (1936). This is the initial study of the Cretaceous biostratigraphy of the Grand Banks. 


\section{Lithostratigraphy}

Sediments several thousand feet thick are believed to underlie the Scotian Shelf and the Grand Banks (Murray 1961, Berger et al. 1966, Hood 1967, Bartlett 1968). It is reasonable to as sume that thick sequences of sedimentary strata also underlie the Labrador Shelf and are a continuation of these deposits. Seismic profiles by Sheridan and Drake (1968) and Grant (1968) suggest several hundred feet of Tertiary and Cretaceous sediments in this area. Sediments underlying the continental shelves of Nova Scotia, Newfoundland and possibly Labrador are probably a continuation of the Gulf Coast and Atlantic Coastal Plain physiographic province.

Cretaceous strata in the Grand Falls section (Fig. 1) are overlain by approximately 800 feet of Paleocene-Eocene and perhaps Miocene mudstone and siltstone. Unconsolidated Pleistocene material, 430 feet thick, overlies the consolidated Tertiary sediments.

Cretaceous and Jurassic (?) sediments approximately 3,600 feet thick were penetrated in the Grand Falls section (Fig. 1). The upper 550 feet of Cretaceous sediment is similar to the overlying Paleocene-Eocene mudstone. In the remainder of the section pure to shaly, silty or sandy limestones are common. The limestone contains abundant coral, bryozoan and Baculites fragments. Ostracods are common in the interspersed mudstone and shale. Dolomite with abundant Inoceramus, other pelecypods and brachiopod fragments is also a characteristic lithic unit. Coal and peat occur approximately 2,100 feet below the Mesozoic-Cenozoic boundary. The lower 1, 200 feet of the Grand Falls section is composed of limestone and shale. The limestone may be quite pure, argillaceous, or may contain algal balls, gastropods, crinoid fragments, and abundant Inoceramus.

Cretaceous strata in the Tors Cove section are overlain by 3,625 feet of Eocene, Miocene and Pleistocene sediments (Fig. 1). The Miocene consists predominantly of mudstone, shale, sandstone and sandy limestone. The Upper and Middle Eocene sediments are represented by sandy limestone, dolomite and sandstone, whereas the Lower Eocene is represented by shale and shaly dolomite.

Well logs indicate that approximately 500 feet of Cretaceous sediments composed of shale, shaly dolomite, sandstone and anhydrite overlie a thick rock salt. The age of the rock salt is questionable. Associated spore and pollen assemblages and for aminifera suggest formation of the original evaporite basin in Jurassic time. Geophysical data indicates the presence of at least two distinct fracture zones and diapiric structures in the immediate area (B. Johnson, personal communication).

The absence of Paleocene sediments in the Tors Cove section suggests non-deposition during Paleocene time, or erosion of the Grand Banks in Eocene time followed by general subsidence since the Miocene. Conversely, the Grand Falls area was low during early Cenozoic time, and was elevated during the Miocene. The movement may have been local and associated with both upward and lateral migration of the salt dome.

The Mesozoic-Cenozoic boundary lies within comparable lithic units on the Grand Banks. The contact is within a mudstone sequence at Grand Falls and within a shale or shaly limestone at Tors Cove. Glauconite is present in various beds in both areas, although it is most abundant at Grand Falls. Pyrite, mica and various rock fragments are scattered throughout the section. Sediment colour is variable with white, cream, light and dark grey, light and dark green and red dominant.

The sediments at Tors Cove (Fig. 1) were deposited in relatively shallow warm water environments. For the purpose of this paper they are divided into three groups. Group I sediments (Cretaceous) were deposited in a restricted, back-reef environment. Group II sediments (Eocene) were deposited in a shallow relatively quiet marine environment, probably seaward from a fluvial influence. Group III sediments (Miocene) are thought to be flood plain deposits and contain dune and beach sands.

The sediments of Group I (Jurassic? -Lower Cretaceous) at Grand Falls were also deposited in a low energy, shallow warm-water environment. Group II (Middle Cretaceous) sediments suggest a transition between flood plain and continental depcsits with periodic warm marine incursions. Similarly, Group III (Upper Cretaceous) sediments represent shallow warm water deposition adjoining a landmass of low relief. 
The sand in the Group I sediments shows recurring suprabaselevel episodes with sand blown or washed into the usually lime producing environment. The silt and mud imply recurring tectonic activity in the source area, causing periodic influxes of fine terrigenous sediment which totally or nearly stopped the production of carbonate sediment. The sandstone of Group III is a typical clear quartz sand, which lies above an unconformity. Carbonate deposition in this area was initiated by the progressive encroachment of a warm shallow transgressing sea. The sand was probably reworked and deposited by these waters and consequently occurs with some of the carbonate layers.

\section{Planktonic Foraminifera}

The lower Cretaceous of the Grand Banks (Fig. 2) is characterized by primitive globigerinids. The dominant forms are Globigerina graysonensis and G. kulgleri. Globigerina helveto-jurassica is sparsely distributed and is commonly represented by only one specimen per sample. Forms resembling Hedbergella delrioensis, H. planispira complex, Globigerinelloides cf. blowi and Heterohelix washitensis are rare. The late Upper Cretaceous fauna of the Grand Falls section is meagre with small Rugoglobigerinids and Globotruncanids scattered throughout. The well is characterized by a considerable amount of down-hole contamination. The Tors Cove strata contains a more prolific Upper Cretaceous planktonic fauna and provides the basis for the utilization of planktonic foraminifera from the Grand Banks for intercontinental correlation of this period.

The Middle Cretaceous boundaries (Fig. 1), represented by the Cenomanian, are defined by major unconformities at Grand Falls. The sediments are typically flood-plain types and contain prolific benthonic microfaunas. Globigerina graysonensis is reduced in numbers but Hedbergella planispira complex is common. Rotalipora greenhornensis is present throughout, whereas $\underline{R}$. appenninica appenninica and Praeglobotruncana stephani are sparse. Heterohelix washitensis is also present.

The microfauna of the Upper Cretaceous is characterized by species of Rugoglobigerina, Hedbergella, Globotruncana and Heterohelix. In many samples, specimens of Rugoglobigerina and Heterohel ix are the only planktonic representatives.

Hedbergella planispira planispira, ${ }_{\text {. }}$ planispira holmdelensis and $\underline{H}$. planispira monmouthensis are common whereas Globigerinelloides aspera aspera is sparsely distributed. Praeglobotruncana helvetica, $P$. inornata and $P$. petaloidea are rare. Globotruncana is well represented as exemplified by Globotruncana arca, G. calcarata, G. contusa, G. fornicata, G. cf. gagnebini, G. gansseri, G. rosetta, G. stuarti stuarti, G. stuarti stuartiformis, G. linneiana linneiana complex, G. subcircumnódifera, G. tricarinata and $G$. ventricosa. Rugoglobigerina rugosa, R. macrocephala and $\underline{R}$. pustulata are the dominant Rugoglobigerinids. Specimens of Heterohelix are commonly smaller than those examined from other areas. Heterohelix globulosa and $\mathrm{H}$. striata are dominant with $\mathrm{H}$. reussi and $\mathrm{H}$. pulchra common to rare. Specimens of Gumbelitria, Gublerina, Planoglobulina, Hastigerinoides, Clavihedbergella and Schackoina have not been observed in the Grand Banks sediment.

Most of the planktonic foraminifera have Tethyan affinities. However, incursions of typically boreal forms occur in the Cenomanian and Maestrichtian. The fauna contains species. comparable to those described by Berggren (1962, 1964) from Scandinavia; Bolli (1951, 1956, 1959), Bronniman (1952 from the Caribbean; Cita (1963), Colom (1955) from the Mediterranean; Edgell (1957) from Australia; Klaus (1960), Mornod (1950) from the Alps; Nakkady and Osman (1954) from Egypt; Olsson (1960, 1964) from New Jersey; Douglas (1969) from California; Subbotina (1953) from the U.S.S. R. and Takayanagi and Iwamoto (1962) from Japan to name only a few. It is obvious that comparable planktonic foraminifera inhabited all of the world oceans during the Cretaceous. Ideal conditions for reproduction and growth would naturally deteriorate progressively from the tropics toward the poles. However, rather uniform oceanic conditions and consequently uniform climate are implied by the widespread nature of the stenobathic planktonic foraminifera.

Cretaceous Faunal Zones

Several species of Cretaceous planktonic foraminifera (Fig. 3) that are useful for inter- 
continental correlation are present in the Grand Banks section. Warm Tethyan waters with associated planktonic foraminifera bathed the area during the Cretaceous. However, the environment lies on the outer limits, in order to make a useful application, of the GlobotruncanaRotalipora lines proposed by Bandy (1967). The latitudinal effect would definitely limit the usefulness of any planktonic zonation in such northern areas. Furthermore, the total geologic range, or geochron, of numerous species is probably not realized because of the periodicity of deep oceanic conditions. Shallow water-reef, back-reef, and flood-plain conditions prevailed for lengthy periods. Consequently, until more information is obtained the zonation for the Grand Banks is tentative. A tripartite division of the Cretaceous is the most plausible at present. The zonation is based upon the most characteristic planktonic species or assemblage. Some have overlapping ranges and others are restricted and short-ranging.

Lower Cretaceous sediments generally contain meagre planktonic faunas. Planktonic foraminifera are also generally sparse in the early Middle Cretaceous (early Cenomanian). However, the Upper Cretaceous (Turonian-Maestrichtian) is characterized by prolific planktonics, many of them good index forms. The zonation presented here is the one thought most applicable to the Grand Banks section. It is both a combination and modification of zones proposed by Bolli (1951, 1957, 1959), Edgell (1957), Klaus (1960), Olsson (1964), and Bandy (1967). There are many others, based on concurrent range or range zones. The attempt in this paper is to relate the Grand Banks to the Atlantic Coastal Plain and European sections in particular and in general to world-wide zonation. Group and formation names are being erected for the Cretaceous sediments underlying the Grand Banks. These distinct lithological units are described and named elsewhere (Bartlett and Smith, 1969).

\section{Paleoecology and Paleooceanography}

Benthonic foraminifera are one of the most useful groups of microorganisms for the purpose of reconstructing the paleoecology of various environments ranging geographically from the marine intertidal to the outer shelf. Planktonic foraminifera are most readily utilized for interpreting the paleooceanography and paleogeography. Other faunal constituents in the Grand Banks sediments such as corals, algal balls, crinoids, brachiopods, Baculites and Inoceramus contribute to an interpretation of the entire environment. Most of the faunas suggest the presence of warm shallow waters adjoining a landmass of low relief. The thick limestone sequences are indicative of warm back-reef to inner-shelf environments. Sand, peat and coal, occurring in a thick mudstone and shale sequence between the limestones, indicate fluctuating conditions in a tectonically active area.

The ecology and distribution of Recent benthonic foraminifera have been determined by numerous investigators. Warm temperate to tropical environments have been described by Bandy and Arnal (1957), Lankford (1959), Phleger (1956, 1964), Uchio (1960) and Walton (1964). Cool temperate benthonic foraminifer al distributions have been interpreted by Parker (1952a, b), Phleger (1952), Bartlett (1962, 1964, 1965, 1966) and Buzas (1965). Subarctic and arctic foraminifera have been investigated by Cooper (1964), Wagner (1964), Leslie (1965) and Vilks (1964, 1969). These studies indicate that benthonic foraminifera define a number of biofacies such as intertidal, beach, lagoonal, estuarine, shelf and slope. Also, that temperature, salinity, depth, substrate, $\mathrm{pH}$, oxygen, nitrates, nitrites, silica and food supply have a direct effect on the distribution of certain benthonic assemblages. Arctic benthonics are dominantly arenaceous whereas tropical forms are dominantly calcareous hyaline. As the environment becomes more variable, for example towards marginal marine conditions, the number of species decreases. Consequently, very few species become dominant and define an environment. Comparable changes in the stratigraphic column could indicate regressions and transgressions of the marine water mass. It is obvious that faunal characters such as arenaceous/calcareous ratios, species number, benthonic/planktonic ratios, test size and numerous other features are extremely important in interpreting ancient environments.

The dominantly calcareous fauna with very few species such as Gyroidina, Bulimina, Globulina, Quinqueloculina and Höeglundina implies a shallow inner-shelf environment influenced by warm marine waters. The presence of ostracods, and the decrease in the number of calcareous species indicates a marine regression and probable fluvial influence. The more stenobathic benthonic forms listed above may have withstood wider environmental variations in the Cretaceous than at present. The evolution of hardier eurybathic forms such as Elphidium, Ammonia, Miliammina, etc. in the Cenozoic may have forced less tolerant forms seaward. 
Planktonic foraminifera are distributed in broad latitudinal belts and narrow vertical zones in the present oceanic watermasses. Recent distributions as noted by Be and Hamlin (1967), Bartlett et al. (1968), Bradshaw (1959) and Parker (1967) can be utilized in interpreting the characteristics of ancient watermasses. Temperatures, salinity and depth are controlling factors in limiting these stenobathic microorganisms. Planktonic foraminifera in tropical waters at present are dominated by Globorotalia, Globigerinoides, Orbulina and Globigerinatella. Conversely, arctic and subarctic waters maintain only a Globigerinid planktonic fauna with Globigerina pachyderma and $G$. bulloides. In addition Bandy $(1960,1964,1967)$ noted that keeled globorotalids, globotruncanids and rotaliporids were limited to a minimum sea temperature of $17^{\circ} \mathrm{C}$. These forms would naturally be restricted to certain latitudinal boundaries. Bartlett (1968) suggested that these boundaries were much broader than previously realized and warm surface waters extended much further north than at present.

The primitive globigerinids in the lower Cretaceous and Hedbergella in the Upper Cretaceous may be boreal forms. Conversely, they may have tolerated extremes or been washed into the back-reef and inner shelf environments in which they are found with associated benthonics. However, the species of Globotruncana, Rugoglobigerina, Rotalipora and Heterohelix are typical Tethyan (Caribbean-Mediterranean) forms. The widespread, almost worldwide nature of these species (see page 7) supports the hypothesis of an extensive warm oceanic watermass during the Cretaceous. Prolific coral development, algal balls, crinoids and oolites on the Grand Banks substantiate this hypothesis. Consequently, oceanic circulation in the North Atlantic during the Cretaceous (Fig. 4) was quite different from that prevalent today. This can be attributed to closeness of continental landmasses, more than one ocean

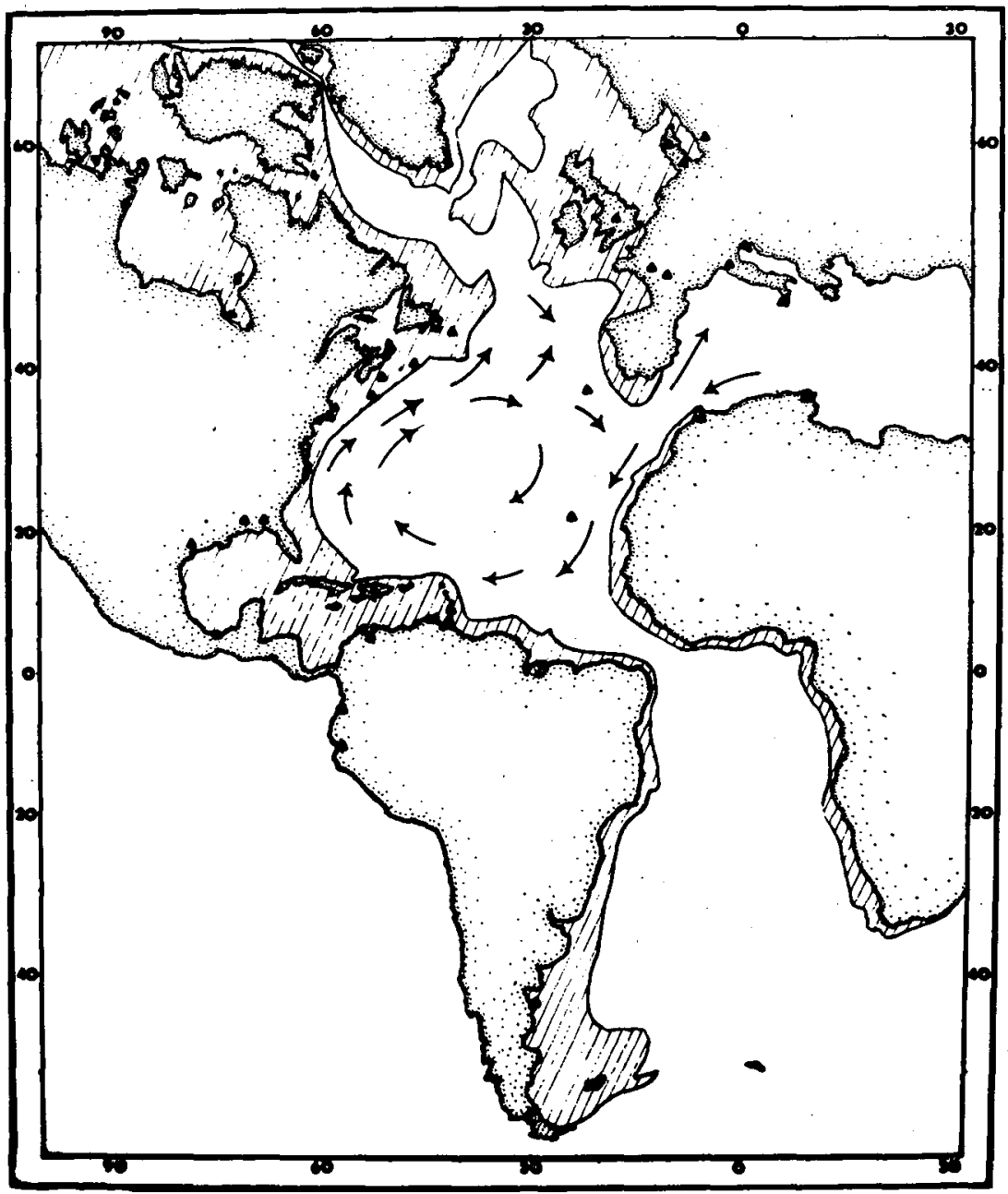

Fig. 4 Suggested North Atlantic current gyre during mid to late Cretaceous. Triangles indicate areas with comparable Cretaceous planktonic foraminiferal assemblages. 
basin, and delay in opening or spreading of more northern areas, e. g. the non-existence of Baffin Bay until Miocene time. Warm surface waters with similar characteristics and faunas (Fig. 4) existed in the Caribbean, New Jersey, Grand Banks, Labrador, England, European and Mediterranean Basins and Scandinavia at least.

\section{Summary}

Several hundred feet of Cretaceous strata underlie the Grand Banks of Newfoundland. The sediments and constituent faunas indicate the prevalence of warm, shallow waters and a basin(s) of subsidence.

Periodic tectonic activity is suggested by major unconformities. These unconformities are recognizable on a world wide scale. A salt dome of Permo-Triassic to Jurassic (?) age was active as late as Eocene time at least.

Upper Jurassic and Lower Cretaceous (Neocomian) sediments contain meagre faunas. The Aptian-Albian is also poorly defined. Microfaunas are also generally sparse in the early Middle Cretaceous (Cenomanian). The Upper Cretaceous (Turonian-Maestrichtian) is characterized by abundant planktonics. The planktonic foraminifera enable a general intercontinental correlation of the Grand Banks strata.

\section{Acknowledgements}

Special thanks are extended to Dr. J. E. Hazel, United States Geological Survey for identification of the ostracods and Dr. W. A. Berggren, Woods Hole Oceanographic Institute and Dr. E. Pessagno, Southwest Center for Advanced Studies, for comments on the planktonic foraminifera. Pan American Oil Company, Calgary, Alberta supplied the samples from the Grand Banks. Technical assistance and laboratory analyses was provided by M. E. Gorveatt, Atlantic Oceanographic Laboratory and J.H. E. McRoberts, E. J. Rive and J. A. Robertson, Queen's University. Dr. L. Smith and Dr. R. Greggs offered stimulating discussions and comments. The helpful criticisms of the manuscript by Dr. B. R. Pelletier, Atlantic Oceanographic Laboratory and Dr. J. L. Usher, Queen's University, are greatly appreciated. Most of the research was financed by N. R. C. Grant A5l04 held in the Department of Geological Sciences, Queen's University while the writer was Visiting Professor during the academic year $1968-1969$.

\section{References cited}

BANDY, O.L., 1960, Planktonic foraminiferal criteria for paleoclimatic zonation, Tohoku Univ., Sci. Repts., Ser. 2 (Geol.), Spec. Vol. No. 4, pp. 1-8, tfs. 1-2.

1964, Cenozoic planktonic foraminiferal zonation, Micropaleo. vol. 10, no. 1, pp. $1-17$, tfs. $1-6$.

, 1967, Cretaceous planktonic foraminiferal zonation, Micropaleo. vol. 13, no. 1, pp. 1-31, tfs. $1-13$.

, and ARNAL, R. E., 1957, Distribution of Recent for aminifer a off west coast of Central Amerca, Am. Assoc. Petr. Geol. Bull., vol. 4l, no. 9, pp. 2037-2053.

BARTLETT, G. A. , 1962, A preliminary study of foraminiferal distribution on the Atlantic Continental Shelf, Southeastern Nova Scotia, Geol. Surv. Can. Paper 64-5, pp. 1-22.

1964, Benthonic foraminiferal ecology in St. Margarets Bay and Mahone Bay, Southeast Nova Scotia, Report BIO 64-8, pp. 1-162, tfs. 39, tabs. 1.

1965, Benthonic for aminiferal ecology in Tracadie Bay, Prince Edward Island, Report BIO 65-3, pp. 1-57. 
BARTLETT, G. A., 1966, Distribution and abundance of foraminifera and Thecamoebina in Miramichi River and Bay, Report BIO 66-2, pp. 1-103.

, 1968, Mid-tertiary stratigraphy of the Continental Slope off Nova Scotia, Maritime Sediments, vol. 4, no. 1.

, VILKS, G., and RAMSAY, A.T.S., 1968, Planktonic foraminifera - their significance in water masses and bottom sediments from the Grand Banks to the Caribbean Sea, Maritime Sediments, vol. 9, no. 1.

, and SMITH, L., 1969, The sequence concept and the Atlantic Continental Margin, Alta. Soc. Petr. Geol. (submitted).

BÉ, A. W. H., 1959, Ecology of Recent planktonic foraminifera, Part 1, areal distribution in the Western North Atlantic, Micropaleo. vol. 5, no. 1, pp. 77-100, pls. 1-2.

, and HAMLIN, W. H. , 1967, Ecology of Recent planktonic foraminifera, Part 3, distribution in the North Atlantic during the summer of 1962, Micropaleo. vol. 13, no. 1, pp. 87-106.

BERGER, J., COR, A. E., BLANCHARD, J. E., and KEEN, M. J., 1966, Morphological and Geophysical studies on the Eastern Seaboard of Canada: The Nova Scotian Shelf, in Continental Drift, University of Toronto Press, pp. 102-113.

BERGGREN, W. A., 1962, Same planktonic foraminifera from the Maestrichtian and type Danian stages of Southern Scandinavia, Stockholm, Univ. Contr. Geol., vol. 9, no. 1, pp. 1-106, pls. $1-14$.

- 1964, The Maestrichtian, Danian and Montian stages and the Cretaceous Tertiary Boundary, Stockholm, Univ., Contr. Geol., vol. 11, no. 5, pp. 103-176.

BOLLI, H. N., 1951, The Genus Globotruncana in Trinidad, B. W. I., Jour. Paleo. vol. 25, no. 2, pp. 187-199, pls. 34-35.

1957, The Genera Praeglobotruncana, Rotalipora, Globotruncana, and a bathomphalus in the Upper Cretaceous of Trinidad, B. W. I., U. S. Nat. Mus. Bull., no. 215, pp. 51-60, pls, $12-14$.

, 1959, Planktonic foraminifera from the Cretaceous of Trinidad, B. W. I. , Bull. Amer. Pal. vol, 39, no. 179, pp. 257-277, pls. 20-23.

BRADSHAW, J.S., 1959, Ecology of living planktonic foraminifera in the north and equatorial Pacific Ocean, Cushman Found. Foram. Res. Contr., vol. 10, pl. 2, pp. 25-64.

BRÖNNIMAN, P., 1952, Globigerinidae from the Upper Cretaceous (CenomanianMaestrichtian) of Trinidad, B. W. I., Bull. Amer. Pal., vol. 34, no. 140, pp. 1-70, pls. $1-4$, tfs. $1-30$.

BUZAS, M. , 1965, The distribution and abundance of foraminifera in Long Island Sound, Smithsonian Misc. Coll., vol. 149, no. 1, pp. 1-89, pls. 1-4.

CITA, Maria B., 1963, Tendencies evolutives des foraminiferes planctiques (Globotruncanae) du Cretace Superieur, In: Evolutionary trends in foraminifera, Amsterdam, Elsevier Publ. Co., pp. $112-138$, tfs. $1-19$.

COOPER, Susan, 1964, Benthonic foraminifera of the Chukchi Sea, Cushman Found. Foram. Res., Contr., vol. 15, pl. 3, pp. 79-104, pls. 5-6, tfs. 1-17.

COLOM, G., 1955, Jurassic-Cretaceous Pelagic sediments of the Western Mediterranean Zone and the Atlantic area, Micropaleo. vol. 1, no. 2, pp. 109-124, pls. 1-5.

CUSHMAN, J.A., 1936, Geology and Paleontology of the Georges Bank Canyons, Part IV, 
Cretaceous and Late Tertiary foraminifera, Geol. Soc. Am. Bull, , vol. 47, pp. 413440 , pls. $1-5$.

CUSHMAN, J.A., 1946, Upper Cretaceous foraminifera of the gulf coastal region of the United States and adjacent areas, U.S. Geol. Survey, Prof. Paper, no. 206, pp. 1-241, pls. 1-66.

DALBIEZ, F., 1955, The Genus Globotruncana in Tunisea, Micropaleo. vol. 1, no. 2, pp. 161171, tfs. $1-10$.

DOUGLAS, R. G. , 1969, Upper Cretaceous planktonic foraminifera in Northern California, Part 1 Systematics, Micropaleo., vol. 15, no. 2, pp. 151-209, pls. 1-11.

EDGELL, H.S., 1957, The Genus Globotruncana in Northwest Australia, Micropaleo. vol. 3, no. 2, pp. 101-126, pls. 1-4.

GIBSON, T.G., HAZEL, J. E., and MELLO, J. F., 1968, Fossiliferous rocks from submarine canyons off the Northeastern United States, U.S. Geol. Survey Prof. Paper 600 D, pp. $222-230$.

GRANT, A. C. , 1968, Seismic-profiler investigation of the continental margin northeast of Newfoundl and, Canadian Jour. Earth Sc., Vol. 5, no. 5, pp. 1187-1198.

HOOD, P. , 1967, Geophysical surveys of the continental shelf south of Nova Scotia, Maritime Sediments, vol. 3 , no. 1, pp. 6-11.

JENNINGS, P.H., 1936, A microfauna from the Monmouth and Basol Rancocas groups of New Jersey, Bull. Amer. Pal., vol. 23, no. 78, pp. 161-234, pls. 28-34.

KING, L. H., MacLEAN, B., BARTLETT, G. A., and JELETZKY, J. A., 1969, Cretaceous strata from the Scotian Shelf, Maritime Sediments, (in press).

KLAUS, J., 1960, Le Complex Schisteux Intermediaire dans le Synclinal de la Gruyere (Prealpes Medianes). Stratigraphie et micropaleontologie, avec l'etude speciale des Globotruncanid de l'Albien, du Cenomamien et du Turonien, Eclogae Geol. Helv., vol. 52 (1959) no. 2, pp. 753-851, pls. 1-8.

LANKFORD, R. R., 1959, Distribution and ecology of foraminifera from East Mississippi Delta Margin, Am. Assoc. Petr. Geol., Bull., vol. 43, no. 9, pp. 2068-2099.

LESLIE, R. J., 1965, Ecology and paleoecology of Hudson Bay foraminifera, Report BIO 65-6, pp. $1-191$.

LOEBLICH, A. R., and TAPPAN, Helen, 1961, Cretaceous planktonic foraminifera, Part 1 Cenomanian, Micropaleo., vol. 7, no. 3, pp. 257-304, pls. 1-8.

MARLOWE, J. I. , 1965, Probable tertiary sediments from a submarine canyon off Nova Scotia, Marine Geology, vol. 3, pp. 263-268.

, and BARTLETT, G. A., 1967, Oligocene-Miocene strata in a submarine canyon off Nova Scotia, Ann. Meeting, SE Sect., Geol. Soc. Am., Tallahassee (Abstr.).

MORNOD, L., 1950, Les Globorotalides du Cretace Superieur de Montsalvens (Preolpes fribourgeoises), Eclogae Geol. Helv., vol. 42 (1949), no. 2, pp. 573-596, p1. 15, tfs. 1-14.

MURRAY, G. E., 1961, Geology of the Atlantic and gulf coastal province of North America, New York, Harper.

NAKKADY, S.E., and OSMAN, A., 1954, The Genus Globotruncana in Egypt, taxonomy and stratigraphic value, Congr. Geol. Internat., 19th Algiers 1952, sec. 13, pp. 75-95, pls. 19-20.

OLSSON, R. K. , 1960, Foraminifera of latest cretaceous and earliest tertiary age in the New Jersey coastal plain, Jour. paleo., vol. 34 , no. 1, pp. 1-58, pls. 1-12. 
, 1964, Late cretaceous planktonic foraminifera from New Jersey and Delaware, Micropaleo., vol. 10, no. 2, pp. 157-188, pls. 1-7.

PARKER, F. L., 1952a, Foraminifera species off Portsmouth, New Hampshire, Museum Comp. Zool. Bull., vol. 106, no. 9, pp. 391-423.

, 1952b, Foraminiferal distribution in the Long Island Sound Buzzards Bay Area, Museum Comp. Zool., Bull, , vol. 106, no. 10, pp. 425-473.

, 1964, Foraminifera from the experimental mohole drilling near Guadalupe Island, Mexico, Jour. Pal., vol. 38, no. 4, pp. 617-636, p1s. 97-102.

1967, Distribution of planktonic foraminifera in Recent deep sea sediments, Micropaleontology of Marine Bottom Sediments Symposium, Cambridge, England.

PESSAGNO, E. A., Jr., 1960, Stratigraphy and micropaleontology of the cretaceous and lower tertiary of Puerto Rico, Micropaleo., vol. 6, no. 1, pp. 87-110, p1s. 1-5.

1967, Upper cretaceous planktonic foraminifera from the western gulf coastal plain, Paleontographica Americana, vol. 5, no. 37, pp. 245-445.

PHLEGER, F.B., 1952, Foraminiferal ecology off Portsmouth, New Hampshire, Museum Comp. Zool. vol. 106, no. 8, pp. 315-390, tfs. 26 , tabs. 18.

, 1956, Significance of living foraminiferal populations along the central Texas coast, Cushman Found. Foram. Res. Contr., vol. 7, pp. 1-106.

, 1964, Patterns of living benthonic foraminifera, Gulf of California, In: Marine Geology of the Gulf of California - A Symposium, Memoir 3, pp. 377-394.

SAITO, T., BURCKLE, L. H., EWING, M., 1966, Lithology and paleontology of the reflective layer horizon A, Sciences, vol. 154, no. 3753, pp. 1173-1176.

SHERIDAN, R. E. , and DRAKE, C. L. , 1968, The seaward extension of the Canadian Appalachians, Can. Jour. Earth Sci., Vol. 5, pp. 337-373.

STEPHENSON, L. W., 1936, Geology and paleontology of the Georges Bank Canyons, P1. 2, Upper Cretaceous fossils from Georges Bank (including species from Banquereau, Nova Scotia), Geol. Soc. Am. Bull.; vol. 47, pp. 367-410.

SUBBOTINA, N. W. , 1953, Fossil for aminifera from the U.S.S. R. : Globigerinidae, Hantkeninidae and Globorotaliidae, Vses, Neft. Nauch. Issled. Geol. - Razved. Inst. (UNIGRI), Trudy, N. ser., vypusk 76, pp. 1-294, 41 pls. (Russian).

TAKAYANAGI, Y., and IWAMOTO, H., 1962, Cretaceous planktonic foraminifera from the Middle Yezo Group of the Ikushumbetshu, Miruto, Hatonosu areas, Hokkaido, Pal. Sac. Japan, Trans. Proc., N. ser; no. 45, pls. 1-10, tfs. 1-18.

VILKS, G. , 1964, Foraminiferal study of East Bay, MacKenzie King Island, District of Franklin: Polar Continental Shelf Project, Canada, Geol. Survey, Paper No. 64-53, pp. $1-26$, tfs. $1-3$.

, 1969, Recent foraminifera in the Canadian Arctic, Micropaleo., vol. 15, no. 1, pp. $35-60$, pls. $1-3$.

WAGNER, Frances, 1962, Faunal report, submarine geology programme, Polar Continental Shelf Project, Isachsen, District of Franklin, Canada Geol. Survey, Paper no. 61-27, pp. $1-10$, tfs. $1-2$.

WALTON, W. R., 1964, Recent for aminifer al ecology and paleoecology, In: Imbrie, J. and Newell, N. Eds. Approaches to Paleoecology, New.York, John Wiley and Sons, Inc. , pp. 151-237. 